\title{
IMPORTANCE OF INFECTION CONTROL THROUGH SCREENING, INSPECTION, PROBLEM ANALYSIS AND TREATMENT PROCEDURES IN DENTAL PRACTICE
}

\author{
Nur Khamilatusy Sholekhah ${ }^{*, * * *}$, Chriswardani Suryawati ${ }^{* *}$, Henry Setyawan ${ }^{\star * *}$, M. Zen Rahfiludin ${ }^{\star * * *}$ \\ *Program Studi Doktor Kesehatan Masyarakat, Fakultas Kesehatan Masyarakat Universitas Diponegoro \\ **Departemen Analisis Kebijakan dan Kesehatan, Fakultas Kesehatan Masyarakat Universitas Diponegoro \\ ${ }^{* \star \star D e p a r t e m e n ~ E p i d e m i o l o g i, ~ F a k u l t a s ~ K e s e h a t a n ~ M a s y a r a k a t ~ U n i v e r s i t a s ~ D i p o n e g o r o ~}$ \\ ****Departemen Gizi, Fakultas Kesehatan Masyarakat Universitas Diponegoro \\ **** Fakultas Kedokteran Gigi Universitas Muhammadiyah Semarang
}

Correspondence: drg.tusy@unimus.ac.id

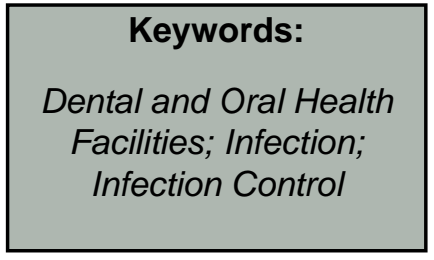

\begin{abstract}
Background: Oral and dental health service facilities are very at risk of infection. It found an increase in the frequency of microorganisms before 33.3\% and after $80 \%$ of treatments in the air of the practice room and an increase in microorganisms before $18.3 \%$ and after $70 \%$ treatment on the surface of the dental unit.

Method: This study aim to report integratively on infection prevention and control guidelines in dental and oral health facilities. The literature review used in this article uses the Systematic Literature Review method by analyzing 618 articles on the scientific search engines Science Direct, ProQuest, Google Schoolar and Pubmed with the criteria for articles related to keywords and 14 articles were collected as literature studies related to material.

Result: Guidelines for the implementation of infection prevention in dental and oral health facilities.

Conclusion: Effective and efficient infection control efforts in dentist practice can reduce the spread of infectious diseases in dental and oral health care facilities.
\end{abstract}

\section{PENDAHULUAN}

Rumah sakit ataupun klinik sebagai tempat pelayanan kesehatan dapat menyebabkan penularan infeksi. Pada tahun 2011 di Inggris sekitar $6,4 \%$ pasien di rumah sakit memperoleh infeksi sebagai akibat dari prosedur, tindakan perawatan atau peralatan medis. ${ }^{1}$ Prevalensi terjadinya infeksi di tempat pelayanan kesehatan di negara maju berkisar 3,5\%-12\%, sedangkan di negara berkembang sebesar $5,7 \%-19,1 \%{ }^{2}$

Terjadinya infeksi silang dikarenakan adanya penularan agen infeksi antara pasien dengan tenaga kesehatan atau sebaliknya. ${ }^{3}$
Penularan infeksi ini dapat terjadi melalui droplet, darah, saliva dan instrument yang terkontaminasi. ${ }^{4}$ Tenaga kesehatan termasuk dokter gigi dan asisten gigi sangat berisiko terhadap penyakit menular, diantaranya yaitu sebesar 1,6\% dokter gigi dan asisten gigi terinfeksi Hepatitis C dan sebesar $6,1 \%$ dokter gigi dan asisten gigi terinfeksi Hepatitis B. 5,6

Pelayanan praktik dokter gigi sangat berisiko terjadi penularan infeksi, didapatkan adanya peningkatan frekuensi mikroorganisme sebelum perawatan sebesar $33,3 \%$ dan sesudah perawatan sebesar $80 \%$ di udara ruang praktik serta peningkatan mikroorganisme sebelum perawatan 
sebesar $18,3 \%$ dan sesudah perawatan $70 \%$ di permukaan dental unit. ${ }^{7}$ Kemudian juga terdapat kontaminasi bakteri pada kaca mulut yang tidak dilakukan pembersihan sebelum sterilisasi dan desinfeksi. ${ }^{8}$

Beberapa studi kasus menunjukkan adanya peningkatan kontaminasi bakteri ketika perawatan gigi dan mulut yang dihasilkan dari aerosol tindakan perawatan gigi dan mulut. ${ }^{9}$ Dengan adanya kondisi seperti ini membuat dokter gigi sangat rentang tertular penyakit infeksi. ${ }^{10}$ Sehingga dengan adanya kondisi tenaga kesehatan gigi yang rentan terkena infeksi, perlu adanya tindakan pencegahan dan pengendalian infeksi dalam fasilitas kesehatan gigi dan mulut. ${ }^{11}$

Melihat adanya risiko terjadinya penularan infeksi di tempat praktik gigi , tidak membuat tenaga kesehatan gigi untuk patuh terhadap protokol pencegahan dan pengendalian infeksi selama praktik. ${ }^{12}$ Hasil penelitian menjelaskan bahwa hanya $6,6 \%$ dokter gigi yang memakai face shield saat praktik, 3,3\% dokter gigi memakai gown saat praktik dan tidak ada satupun dokter gigi yang menggunakan rubber dam saat praktik. ${ }^{13}$

Sebagian besar tenaga kesehatan gigi sudah memiliki pengetahuan yang baik tentang upaya pencegahan dan pengendalian infeksi di tempat praktik, tetapi tingkat kepatuhan tenaga kesehatan gigi dalam menerapkan standar pencegahan dan pengendalian infeksi masih rendah. ${ }^{14}$ Tenaga kesehatan tidak hanya dituntut untuk meningkatkan keterampilan sesuai bidang ilmunya, namun juga harus meningkatkan profesionalismenya untuk patuh melakukan perawatan berdasar standar pencegahan dan pengendalian infeksi. ${ }^{15}$

\section{Sudah ada pedoman pelaksanaan} pencegahan dan pengendalian infeksi (PPI) di fasilitas kesehatan dimana komponen utama yang yang harus dilaksanakan dan dipatuhi adalah kewaspadaan standar, yaitu kebersihan tangan,
Alat Pelindung Diri (APD), dekontaminasi peralatan perawatan pasien, kesehatan lingkungan, pengelolaan limbah, penatalaksanaan linen, perlindungan kesehatan petugas, penempatan pasien hygiene respirasi/etika batuk dan bersin, praktik menyuntik yang aman dan praktik lumbal pungsi yang aman ${ }^{15,16}$ Tetapi melihat situasi dan kondisi saat ini, dimana terdapat pertambahan kasus penyakit infeksi seperti adanya ancaman COVID-19 di tahun 2019, peningkatan penyakit HIV dan Hepatitis, maka dari pedoman tersebut dirasa masih terdapat beberapa kekurangan dan perlu ditambahkan upaya pencegahan infeksi secara komprehensif. ${ }^{17,18}$

Upaya kontrol infeksi yang efektif dan efisien pada praktik dokter gigi dapat mengurangi penyebaran penyakit infeksi di fasilitas pelayanan kesehatan gigi dan mulut. ${ }^{19}$ Dengan adanya pedoman pencegahan dan pengendalian infeksi di fasilitas kesehatan, bertujuan agar terwujud pelayanan kesehatan yang bermutu dan dapat menjadi acuan bagi semua pihak yang terlibat dalam pelaksanaan pencegahan dan pengendalian infeksi di dalam fasilitas pelayanan kesehatan serta dapat melindungi masyarakat dan mewujudkan patient safety yang pada akhirnya juga akan berdampak pada efisiensi pada manajemen fasilitas kesehatan dan peningkatan kualitas pelayanan. ${ }^{16}$ Sehingga penting untuk menyusun pedoman pencegahan dan pengendalian infeksi di fasilitas pelayanan kesehatan gigi dan mulut dimulai dari skrining pasien, inspeksi dokter gigi, analisis masalah gigi dan mulut dan prosedur perawatan gigi dan mulut.

Langkah awal upaya pencegahan dan pengendalian infeksi di fasilitas kesehatan gigi dan mulut yang penting dilakukan adalah melakukan skrining pasien yang bertujuan untuk mencegah terjadinya infeksi dari penyakit menular yang diperoleh dari pasien. Terdapat kasus bahwa 6 dari 
301 pasien terpapar virus Hepatitis B ketika datang di fasilitas kesehatan gigi dan mulut untuk dilakukan perawatan. ${ }^{20}$ Inspeksi pada dokter gigi dilakukan terkait vaksinasi yang sudah dilakukan oleh tenaga medis yang bertujuan sebagai lapisan perlindungan tambahan terhadap patogen tertentu dari pasien ke dokter gigi. ${ }^{21,22}$

Sebelum melakukan perawatan gigi dan mulut, perlu melakukan analisis masalah gigi dan mulut untuk mengidentifikasi masalah kesehatan gigi dan mulut yang bersifat infeksius atau tidak dan yang termasuk tindakan invasif atau non invasif. ${ }^{19,23,24}$ Selama perawatan gigi dan mulut perlu diperhatikan prosedur sebelum, saat dan setelah perawatan dengan menerapkan upaya pencegahan dan pengendalian infeksi seperti penggunaan antimicrobial mouthwash, rubber dam, alat pelindung diri dan vacuum aerosol yang dapat mengurangi penyebaran agen infeksius penyebab penyakit melalui droplet dan aerosol.24,25,26

\section{Berdasarkan penjelasan diatas terkait} pencegahan dan pengendalian infeksi di fasilitas kesehatan gigi dan mulut, diperlukan suatu pedoman yang dapat memberikan masukan dan solusi bagi instansi terkait maupun pihak lain untuk mengurangi penyebaran infeksi di fasilitas kesehatan gigi dan mulut. Maka, tujuan penelitian ini untuk melaporkan secara integrative tentang pedoman pencegahan dan pengendalian infeksi di fasilitas kesehatan gigi dan mulut.

\section{METODE PENELITIAN}

\section{Pencarian Artikel yang Relevan}

Artikel disusun dengan teknik studi pustaka dengan mengumpulkan data dan sumber terkait tema dan masalah yang akan dianalisis. Strategi pencarian sistematis dilakukan menggunakan database terkomputerisasi dari Science Direct, ProQuest, Google Schoolar dan Pubmed dengan mencari artikel ilmiah dengan tahun terbit artikel
2016-2021 dan dapat diakses full text. Strategi pencarian dibangun berdasarkan kata kunci, seperti kontrol infeksi, pencegahan dan pengendalian infeksi, infeksi silang, skrining pasien, inspeksi dokter gigi, analisis masalah gigi dan mulut serta prosedur perawatan gigi dan mulut. Data yang digunakan untuk penelitian ini berupa data dari artikel-artikel dengan menggunakan kata kunci (Tabel 1).

Tabel 1. Kata Kunci

\begin{tabular}{|c|c|c|c|}
\hline $\begin{array}{l}\text { Search } \\
\text { Engine }\end{array}$ & $\begin{array}{c}\text { Tahun } \\
\text { Pencarian }\end{array}$ & Kata Kunci & $\begin{array}{c}\text { Jumlah } \\
\text { Artikel }\end{array}$ \\
\hline $\begin{array}{l}\text { Google } \\
\text { Scholar }\end{array}$ & $\begin{array}{c}2016 \text { - } \\
2021\end{array}$ & $\begin{array}{l}\text { "infection control } \\
\text { in dental } \\
\text { practice", "cross } \\
\text { infection in dental } \\
\text { practice", } \\
\text { "managing of } \\
\text { dental problems" } \\
\text { and "treatment } \\
\text { procedures and } \\
\text { prevention of } \\
\text { cross infection in } \\
\text { dental practice" }\end{array}$ & 246 \\
\hline Pubmed & $\begin{array}{c}2016 \text { - } \\
2021\end{array}$ & $\begin{array}{l}\text { "dentist } \\
\text { inspection" } \\
\text { "hepatitis vaccine } \\
\text { for dentist" and } \\
\text { "covid vaccine for } \\
\text { dentist" }\end{array}$ & 92 \\
\hline ProQuest & $\begin{array}{c}2016- \\
2021\end{array}$ & $\begin{array}{l}\text { "skrining patient } \\
\text { in dental practice" } \\
\text { and "prevention } \\
\text { of cross infection } \\
\text { in dental practice" }\end{array}$ & 40 \\
\hline $\begin{array}{l}\text { Science } \\
\text { Direct }\end{array}$ & $\begin{array}{c}2016- \\
2021\end{array}$ & $\begin{array}{l}\text { "skrining patient } \\
\text { in dental practice" } \\
\text { and "prevention } \\
\text { of cross infection } \\
\text { in dental practice" }\end{array}$ & 240 \\
\hline
\end{tabular}

\section{Kriteria Seleksi Untuk Semua Artikel}

Artikel disaring sesuai dengan kriteria inklusi. Artikel penelitian yang sesuai dengan kriteria inklusi dibuat ringkasan untuk memperjelas analisis abstrak dan dianalisis sesuai dengan tujuan dari penelitian. Artikel disaring melalui 2 filter pemasangan: pertama penyaringan dilakukan oleh penulis pertama melalui judul dan abstrak dengan kriteria: (i) terkait kontrol infeksi, (ii) terkait skrining pasien, (iii) terkait inspeksi dokter gigi, (iv) terkait analisis masalah gigi dan mulut, (v) terkait prosedur 
perawatan gigi dan mulut, (vi) terkait dengan fasilitas kesehatan gigi dan mulut. Memasuki tahap kedua, dilakukan penyaringan ulang hingga tuntas artikel dan disetujui oleh penulis kedua.

\section{Ekstraksi dan Sintesis Data}

Dari artikel ilmiah yang berhasil dihimpun, dilakukan analisis dan evaluasi berbagai macam hasil penelitian dan literatur tentang tujuan penulisan artikel. Hasilnya sebagai berikut diekstraksi: Pentingnya membuat protokol perawatan gigi dan mulut dalam dalam pencegahan dan pengendalian infeksi di fasilitas kesehatan gigi dan mulut, tujuan skrining pasien, tujuan inspeksi dokter gigi, peran analisis masalah gigi dan mulut dan prosedur perawatan gigi dan mulut dalam pencegahan dan pengendalian infeksi.

\section{Pencarian Literatur dan Kesesuaian Artikel}

Bagan 1 menyajikan diagram alur prosedur pemilihan literatur. Sastra sistematis pencarian menghasilkan 618 artikel, setelah proses penyaringan 14 artikel dipilih sebagai studi literature materi terkait pedoman perawatan gigi dan mulut dalam dalam pencegahan dan pengendalian infeksi di fasilitas kesehatan gigi dan mulut (Gambar 1). Artikel dianalisa kesesuaiannya karena mampu memberikan masukan dan informasi yang berkaitan langsung dengan hal tersebut tema diskusi. Alur penelitian dapat dilihat pada bagan berikut :

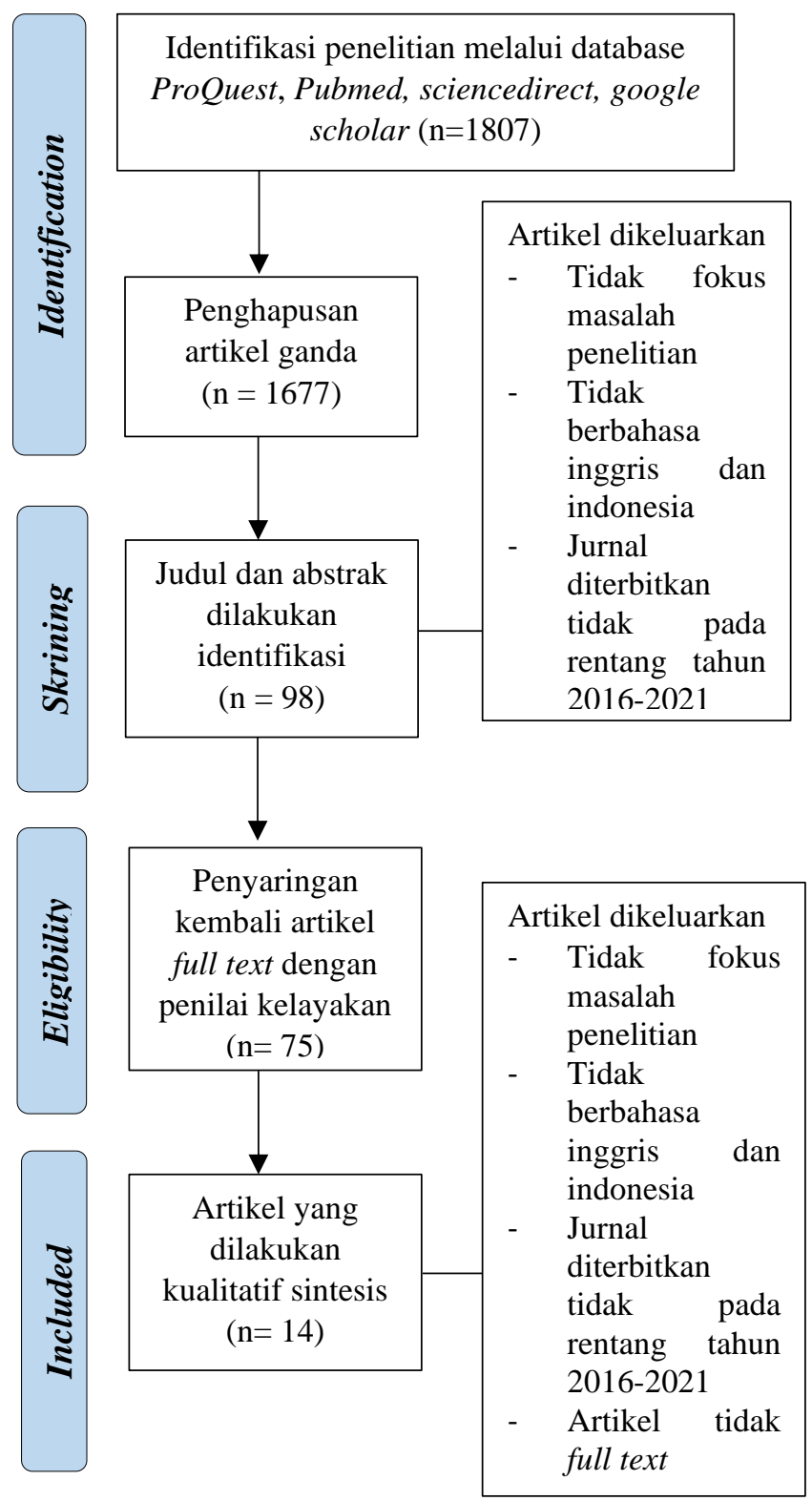

Bagan 1. Alur Penelitian

\section{HASIL PENELITIAN}

Tabel 2 menyajikan temuan utama dari setiap artikel. Mereka dianalisis kemudian disimpulkan Poin tujuan utama dari 14 artikel tersebut, kemudian ditemukan 3 poin yaitu artikel pentingnya membuat protokol perawatan gigi dan mulut dalam dalam pencegahan dan pengendalian infeksi di fasilitas kesehatan gigi dan mulut, tujuan skrining pasien, tujuan inspeksi dokter gigi, peran analisis 
masalah gigi dan mulut dan prosedur perawatan gigi dan mulut dalam pencegahan dan pengendalian infeksi. Tabel 3 menampilkan artikel mana saja yang membahas poin-poin yang sesuai dengan tujuan utama yang telah ditetapkan dan ditemukan. Sebagian besar artikel membahas pentingnya skrining pasien dalam upaya pencegahan dan pengendalian infeksi silang di praktik dokter gigi. 27,28,29,30 kemudian tentang inspeksi dokter gigi dan asisten dokter gigi pentingnya melakukan vaksinasi $i^{31,27,5,6,32,33}$, lalu tentang pentingnya analisis masalah gigi dan mulut dengan mengkategorisasi tingkat urgensi masalah gigi dan mulut ${ }^{27,29,30}$, serta pentingnya prosedur perawatan gigi dan mulut dalam pencegahan dan pengendalian infeksi di praktik dokter gigi.9,31,34, $14,35,27,29,30,32,33$

Tabel 2.

Pedoman Pencegahan dan Pengendalian Infeksi di Fasilitas Kesehatan Gigi dan Mulut

\begin{tabular}{|c|c|c|c|}
\hline Penulis & $\begin{array}{c}\text { Jenis } \\
\text { Penelitian }\end{array}$ & Subjek Penelitian & Hasil Temuan \\
\hline $\begin{array}{l}\text { Chung, } \\
\text { Rakkoo et al } \\
(2020)\end{array}$ & $\begin{array}{l}\text { Cross } \\
\text { Sectional }\end{array}$ & $\begin{array}{l}\text { Pasien yang melakukan perawatan gigi dari } \\
\text { bulan Februari } 2016 \text { sampai Maret } 2018 \text { di } \\
\text { New York }\end{array}$ & $\begin{array}{l}\text { Skrining HIV perlu dilakukan secara rutin } \\
\text { dalam perawatan gigi dan mulut. }{ }^{33}\end{array}$ \\
\hline $\begin{array}{l}\text { Ali, AA et al } \\
(2017)\end{array}$ & $\begin{array}{l}\text { Cross } \\
\text { Sectional }\end{array}$ & $\begin{array}{l}214 \text { dokter gigi di } 6 \text { Perguruan Tinggi } \\
\text { Kedokteran Gigi yang berbeda di Pakistan }\end{array}$ & $\begin{array}{l}\text { Skrining dapat digunakan untuk } \\
\text { mendeteksi ada atau tidaknya penyakit; } \\
\text { diagnosis yang tepat harus dilakukan } \\
\text { dan untuk itu rujukan yang tepat harus } \\
\text { diberikan oleh dokter gigi.. }\end{array}$ \\
\hline $\begin{array}{l}\text { Kobza, J., } \\
\text { Pastuszka, S., } \\
\text { Bragoszewska, } \\
\text { E (2018) }\end{array}$ & $\begin{array}{l}\text { Quasy } \\
\text { Eskperime } \\
\text { nt }\end{array}$ & 2 Klinik Gigi & $\begin{array}{l}\text { Bioaerosol, perawatan gigi professional, } \\
\text { risiko kesehatan, kontrol infeksi dalam } \\
\text { ruangan. }^{9}\end{array}$ \\
\hline $\begin{array}{l}\text { Hussein, L.M., } \\
\text { Ali, S.D., } \\
\text { Twair, A.MJ } \\
\text { (2020) }\end{array}$ & $\begin{array}{l}\text { Cross } \\
\text { Sectional }\end{array}$ & $\begin{array}{l}\text { Seluruh dokter gigi yang berpraktik di klinik } \\
\text { dokter gigi Iraqi di Kota Al-Najaf, Iraq }\end{array}$ & $\begin{array}{l}\text { Pengetahuan dan sikap dokter gigi } \\
\text { dalam menerapkan kontrol infeksi di } \\
\text { tempat praktik. }{ }^{35}\end{array}$ \\
\hline $\begin{array}{l}\text { Abraham, J.P } \\
\text { et al (2018) }\end{array}$ & $\begin{array}{l}\text { Quasy } \\
\text { Eskperime } \\
n t\end{array}$ & Alat Bur kedokteran gigi & $\begin{array}{l}\text { Tujuan sterilisasi instrumen dalam } \\
\text { kedokteran gigi adalah untuk lindungi } \\
\text { pasien dari kontaminasi silang melalui } \\
\text { instrumen. Proses sterilisasi membuat } \\
\text { instrumen bebas dari semua kehidupan } \\
\text { mikroba, termasuk spora bakteri, yang } \\
\text { sulit dimusnahkan. }\end{array}$ \\
\hline $\begin{array}{l}\text { Ayub, Kinza et } \\
\text { al (2019) }\end{array}$ & $\begin{array}{l}\text { Cross } \\
\text { Sectional }\end{array}$ & $\begin{array}{l}71 \text { petugas rumah sakit, } 40 \text { demonstrator dan } \\
\text { trainer di Rumah Sakit Gigi Internasional Islam } \\
\text { Islamabad, Pakistan }\end{array}$ & $\begin{array}{l}\text { Alat dan perlengkapan pelindung pribadi } \\
\text { harus digunakan selama pekerjaan klinis } \\
\text { rutin. Meskipun pasien berstatus } \\
\text { infeksius, standar keamanan universal } \\
\text { harus diterapkan untuk setiap pasien. }{ }^{14}\end{array}$ \\
\hline $\begin{array}{l}\text { Bourgeois, } \\
\text { Denis et al } \\
(2017)\end{array}$ & $\begin{array}{l}\text { Cross } \\
\text { Sectional }\end{array}$ & $\begin{array}{l}3765 \text { dokter gigi umum yang praktik pribadi di } \\
\text { France }\end{array}$ & $\begin{array}{l}\text { (1)Pembersihan } \\
\text { instrumen yang dapat digunakan } \\
\text { kembali; (2) Verifikasi biologis siklus } \\
\text { sterilisasi - Memantau prosedur } \\
\text { sterilisasi uap; (3) Performa autoclave } \\
\text { dan pengetahuan praktisi tentang } \\
\text { penggunaan autoclave; (4) Pemantauan } \\
\text { dan dokumentasi prosedur sterilisasi - } \\
\text { Melacak dan menelusuri } \\
\text { instrumentasi. }{ }^{32}\end{array}$ \\
\hline $\begin{array}{l}\text { Yulianto, } \\
\text { H.D.K et al } \\
(2020)\end{array}$ & Review & Klinik Gigi & $\begin{array}{l}\text { Semua prosedur non-emergency untuk } \\
\text { sementara dan skrining pasien dengan } \\
\text { cermat untuk gejala yang mungkin } \\
\text { dicurigai sebagai infeksi COVID-19. }{ }^{33}\end{array}$ \\
\hline
\end{tabular}




\begin{tabular}{lll}
\hline Abbas, $\mathrm{Al}$ & Cross & 246 dokter gigi dan 263 asisten dokter gigi di \\
Kasem et al & Sectional & Yemen \\
$(2018)$ & &
\end{tabular}

Hanya $30,1 \%$ dokter gigi dan asisten dokter gigi yang divaksinasi terhadap infeksi virus Hepatitis B. Terpapar HBV pada tubuh akan berpotensi menyebabkan infeksi. Namun hanya sebagian kecil petugas kesehatan gigi yang divaksinasi, jadi semua petugas kesehatan gigi perlu divaksinasi sebagai kebijakan dan memastikan lingkungan kerja yang lebih aman. ${ }^{5}$

\begin{tabular}{lcc}
\hline Al-Kebsi, A.M & Cross & Dokter gigi dan asisten dokter gigi di Yemen \\
et al (2017) & Sectional &
\end{tabular}

Prevalensi infeksi Hepattis C (HCV) tinggi di antara dokter gigi dan asisten dokter gigi, berpotensi menyebabkan infeksius penularan HCV ke dokter gigi dan asisten gigi. Oleh karena itu perlu memastikan lingkungan kerja yang lebih aman dalam pengendalian dan pencegahan infeksi HCV. ${ }^{6}$

Alharbi, Ali et Review Klinik Gigi

al (2020)

Pedoman perawatan gigi dan mulut dengan protokol pencegahan infeksi : skrining pasien dan kategorisasi perawatan gigi dan mulut (emergency, urgent, non-urgent, dan elective). ${ }^{31}$

\begin{tabular}{lll}
\hline Diegritz, & Case & Klinik Gigi Departemen Konservasi dan \\
Chistian et al & Report & Periodontologi di Munich \\
$(2020)$ & &
\end{tabular}

Pedoman perawatan gigi dan mulut dengan protokol pencegahan infeksi : sebelum perawatan, saat perawatan dan setelah perawatan gigi dan mulut. ${ }^{34}$

\begin{tabular}{lll}
\hline Nazir, Asif & Cross & Dokter gigi di Institute of Dentistry Multan, \\
$(2018)$ & Sectional & $\begin{array}{l}\text { de'Montmorency College of Dentistry Lahore, } \\
\text { CMH Medical dan Dental College Lahore dari } \\
\text { April and May } 2017\end{array}$
\end{tabular}

\begin{tabular}{lll}
\hline Bialowska, & Quasy & Bahan kedokteran gigi berupa resin komposit \\
Joanna (2020) & Eksperime & dengan syringe \\
& $n$
\end{tabular}

Faktor penting dalam pengendalian infeksi silang adalah mengganti sarung tangan dan masker untuk setiap pasien selama perawatan gigi untuk mencegah penyebaran infeksi dari pasien ke pasien. ${ }^{27}$

Terdapat risiko kontaminasi resin komposit dengan syringe melalui kontak langsung, di mana operator dapat mentransfer agen infeksi dari pasien melalui sarung tangan atau peralatan gigi. Tangan dokter gigi, yang sering terkontaminasi dengan saliva atau darah pasien, merupakan pembawa utama mikroorganisme ke berbagai permukaan, termasuk resin komposit dengan syringe. ${ }^{29}$

Tabel 3.

Literatur Tujuan Utama

\begin{tabular}{|c|c|c|c|c|}
\hline \multirow[b]{2}{*}{ Penulis } & \multicolumn{4}{|c|}{ Tujuan Utama } \\
\hline & $\begin{array}{l}\text { Skrining pasien } \\
\text { dalam upaya } \\
\text { pencegahan dan } \\
\text { pengendalian } \\
\text { infeksi silang di } \\
\text { praktik dokter gigi }\end{array}$ & $\begin{array}{l}\text { Inspeksi dokter gigi } \\
\text { dan asisten dokter } \\
\text { gigi melakukan } \\
\text { vaksinasi }\end{array}$ & $\begin{array}{c}\text { Analisis masalah gigi } \\
\text { dan mulut dengan } \\
\text { mengkategorisasi } \\
\text { tingkat urgensi } \\
\text { masalah gigi dan } \\
\text { mulut }\end{array}$ & $\begin{array}{c}\text { Prosedur perawatan } \\
\text { gigi dan mulut dalam } \\
\text { pencegahan dan } \\
\text { pengendalian infeksi di } \\
\text { praktik dokter gigi }\end{array}$ \\
\hline $\begin{array}{l}\text { Chung, } \\
\text { Rakkoo et } \\
\text { al }\end{array}$ & $\sqrt{ }$ & - & - & - \\
\hline Ali, AA et al & $\sqrt{ }$ & - & - & - \\
\hline
\end{tabular}




\begin{tabular}{|c|c|c|c|c|}
\hline $\begin{array}{l}\text { Kobza, J., } \\
\text { Pastuszka, } \\
\text { S., } \\
\text { Bragoszew } \\
\text { ska, E }\end{array}$ & - & - & - & $\sqrt{ }$ \\
\hline $\begin{array}{l}\text { Hussein, } \\
\text { L.M., Ali, } \\
\text { S.D., } \\
\text { Twair, } \\
\text { A.MJ }\end{array}$ & - & $\sqrt{ }$ & - & $\sqrt{ }$ \\
\hline $\begin{array}{l}\text { Abraham, } \\
\text { J.P et al }\end{array}$ & - & - & - & $\sqrt{ }$ \\
\hline $\begin{array}{l}\text { Ayub, } \\
\text { Kinza et al }\end{array}$ & - & - & - & $\sqrt{ }$ \\
\hline $\begin{array}{l}\text { Bourgeois, } \\
\text { Denis et al }\end{array}$ & - & - & - & $\sqrt{1}$ \\
\hline $\begin{array}{l}\text { Yulianto, } \\
\text { H.D.K et al }\end{array}$ & $\sqrt{ }$ & $\sqrt{ }$ & $\sqrt{ }$ & $\sqrt{ }$ \\
\hline $\begin{array}{l}\text { Abbas, Al } \\
\text { Kasem et } \\
\text { al }\end{array}$ & - & $\sqrt{ }$ & - & - \\
\hline $\begin{array}{l}\text { Al-Kebsi, } \\
\text { A.M et al }\end{array}$ & - & $\sqrt{ }$ & - & - \\
\hline $\begin{array}{l}\text { Alharbi, Ali } \\
\text { et al }\end{array}$ & $\sqrt{ }$ & - & $\sqrt{ }$ & $\sqrt{1}$ \\
\hline $\begin{array}{l}\text { Diegritz, } \\
\text { Chistian et } \\
\text { al }\end{array}$ & $\sqrt{ }$ & - & $\sqrt{ }$ & $\sqrt{ }$ \\
\hline Nazir, Asif & - & $\sqrt{ }$ & - & $\sqrt{ }$ \\
\hline $\begin{array}{l}\text { Bialowska, } \\
\text { Joanna }\end{array}$ & - & $\sqrt{ }$ & - & $\sqrt{ }$ \\
\hline
\end{tabular}

Joanna

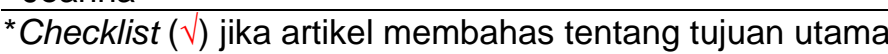

\section{DISKUSI}

Pelayanan kesehatan merupakan faktor penting dari kesehatan namun tidak yang paling berpengaruh, pemanfaatan pelayanan kesehatan yang tersedia dan optimal adalah sarana penting untuk meningkatkan status kesehatan seseorang. ${ }^{36}$ Suatu unit pelayanan kesehatan yang bermutu harus memiliki dimensi keselamatan, yaitu mencegah terjadinya infeksi silang pada tenaga kesehatan dan pasien.2,37 Tenaga pelayanan kesehatan di Indonesia termasuk pelayanan kesehatan gigi dan mulut mempunyai kewajiban untuk selalu memenuhi salah satu kriteria standar pelayanan kedokteran gigi di Indonesia, yaitu melaksanakan Pencegahan dan Pengendalian Infeks (PPI). Prosedur pelaksanaan tentang Pencegahan dan Pengendalian Infeksi tersebut harus dilaksanakan pada semua fasilitas pelayanan kesehatan gigi dan mulut di seluruh Indonesia. ${ }^{15}$ Terdapat ketakutan dan kecemasan praktisi kesehatan gigi terhadap risiko terjadinya infeksi silang. Sehingga perlu ada upaya edukasi untuk meningkatkan kontrol infeksi, melatih cara untuk mencegah terjadinya infeksi silang antara dokter dengan pasien dan mengedukasi untuk selalu bekerja dengan prinsip patient safety. ${ }^{38}$

Pelayanan kesehatan gigi dan mulut merupakan tindakan yang berisiko terpajan cairan tubuh pasien. Petugas kesehatan yang menangani daerah gigi dan mulut secara rutin mengalami paparan yang berulang terhadap mikroorganisme yang ada dalam darah dan saliva. Infeksi silang di bidang kedokteran gigi adalah perpindahan 
penyebab penyakit di antara pasien, dokter gigi dan petugas kesehatan dalam lingkungan pelayanan kesehatan gigi. ${ }^{21}$ Penularan infeksi gigi dapat terjadi melalui tetesan udara yang terinfeksi, darah, saliva, dan instrumen yang terkontaminasi sekresi. ${ }^{4,3}$ Sehingga diperlukan upaya pencegahan dan pengendalian infeksi di tempat praktik dokter gigi untuk menghindari terjadinya infeksi silang antara dokter gigi, asisten gigi dan pasien. ${ }^{13,39}$

Untuk mengetahui riwayat medis seseorang perlu dilakukan skrining ke pasien yang bertujuan untuk mengidentifikasi pasien yang berisiko tinggi menularkan atau tertular infeksi. Namun, banyak patogen yang dapat berada dalam status karier tanpa gejala atau menular sebelum gejala penyakit klinis muncul. Oleh karena itu, prinsip yang mendasari pengendalian infeksi silang melibatkan pengambilan tindakan pencegahan standar untuk meminimalkan risiko penularan terlepas dari status kesehatan pasien atau petugas layanan kesehatan. Pengendalian infeksi silang yang efektif membutuhkan kewaspadaan terus-menerus dan melibatkan upaya gabungan dari seluruh tim gigi. ${ }^{1}$ Skrining awal pasien gigi dalam upaya pencegahan COVID-19 dilakukan tanpa kontak. Pasien diarahkan untuk mengisi kuesioner online yang dikirim melalui email atau di website. Asesmen awal dilakukan untuk mengetahui status tingkat risiko pasien terkena COVID-19. Hasil evaluasi asesmen skrining awal yang terdiri dari status risiko pasien terpapar COVID-19 dan tatalaksana perawatan gigi yang sesuai dengan kondisi pasien dikomunikasikan kepada pasien melalui konsultasi tele atau video. ${ }^{27}$ Perlu dilakukan upaya skrining setiap pasien tanpa gejala (asimtomatik) dengan cermat dan mempertimbangkan setiap pasien yang potensial sebagai pembawa COVID-19 tanpa gejala. ${ }^{29}$ CDC merekomendasikan perlunya skrining HIV rutin di semua rangkaian layanan kesehatan untuk mendiagnosis orang yang terinfeksi HIV tanpa gejala. ${ }^{40}$

Risiko penularan infeksi pada petugas gigi tergantung pada tugas dan wilayah kerjanya. Kategori risikonya adalah sebagai berikut : 1) kategori I : tugas yang melibatkan pajanan terhadap darah, cairan tubuh atau jaringan seperti dalam prosedur yang dilakukan oleh dokter gigi, perawat gigi, dan asisten; 2) kategori II : tugas yang tidak melibatkan pajanan rutin terhadap darah, cairan tubuh atau jaringan seperti pada staf pendukung yang terlibat dalam pembersihan petugas klinik atau laboratorium yang terlibat dalam penanganan instrumen dan cetakan; serta kategori III: tugastugas yang tidak melibatkan paparan darah, cairan tubuh atau jaringan sama sekali. Misalnya, resepsionis atau staf administrasi di kantor gigi. Semua staf gigi yang termasuk dalam kategori I dan kategori II diinstruksikan melakukan melakukan imunisasi untuk melindungi diri mereka sendiri dan pasien mereka. ${ }^{1,21} 44 \%$ dari dokter gigi yang disurvei menganggap HIV sebagai penyakit menular yang paling mengkhawatirkan, $41 \%$ menganggap HBV sebagai penyakit menular paling serius. Namun, risiko tertular HBV dilaporkan jauh lebih besar daripada risiko HIV di antara ahli anestesi gigi non-imun dan risiko kematian akibat infeksi HBV lebih besar daripada risiko HIV. ${ }^{31} \mathrm{Di}$ seluruh dunia sekitar 300-400 juta orang adalah pembawa hepatitis $B$ kronis. Untuk mencegah virus Hepatitis B perlu dilakukan vaksinasi melawan HBV. Imunisasi HBV $(71,6 \%)$ hampir sebanding dengan hasil terbaru di Inggris (86\% diimunisasi). ${ }^{31}$ Imunisasi memberikan lapisan perlindungan tambahan terhadap penularan patogen tertentu dari pasien ke dokter gigi. ${ }^{5}$

Upaya pencegahan dan pengendalian infeksi dalam perawatan gigi dan mulut perlu melakukan identifikasi tindakan gigi yang berisiko menyebabkan infeksi atau tidak. Tindakan yang 
bersifat invasif sangat rentan terhadap penularan infeksi karena dalam tindakan perawatan tersebut kontak dengan saliva (air liur) dan darah pasien. ${ }^{23,24}$ Selain itu juga perlu mengidentifikasi perawatan gigi dan mulut berdasar kebutuhan mendesak pasien dan berfokus pada penatalaksanaannya dengan prosedur invasif minimal, kategorisasi perawatan gigi menurut urgensi perawatan yang diperlukan dan risiko serta manfaat yang terkait dengan setiap perawatan, mengidentifikasi perawatan gigi yang diperlukan untuk setiap pasien dan risiko serta manfaat yang terkait dengan perawatan itu. ${ }^{29,30}$

Dalam perawatan gigi dan mulut perlu dipertimbangkan pedoman perawatan gigi dan mulut mulai dari sebelum perawatan, saat perawatan dan setelah perawatan. ${ }^{32}$ Sebelum melakukan perawatan gigi dan mulut perlu menggunakan rubber dam dengan tujuan untuk meminimalisir saliva dan mencegah transmisi partikel mikroorganisme yang terkandung dalam aerosol saat preparasi dengan handpiece dan menggunakan ultrasonic scaler. ${ }^{41}$ Efektivitas rubber dam dalam mencegah penularan mikroorganisme sebesar 95\% - 99\%.32,42 Penggunaan antimicrobial mouthrinse untuk pasien juga penting dilakukan sebelum perawatan gigi yang bertujuan untuk mencegah penyebaran agen infeksius penyebab penyakit yang dapat menyebar melalui droplet dan aerosol ketika perawatan gigi dan mulut. ${ }^{43}$ Personal protective equipment (PPE) atau yang dikenal sebagai alat pelindung diri (APD) merupakan alat yang digunakan oleh tenaga kesehatan setiap hari untuk melindungi diri mereka sendiri, pasien dan orang lain saat melakukan tindakan medis. APD ini dapat melindungi tenaga kesehatan dari segala potensi mikroorganisme atau bahan toksik yang digunakan dalam bidang kedokteran maupun kedokteran gigi. ${ }^{22,44}$ Selama perawatan gigi dan mulut perlu menggunakan vacuum aerosol dan melakukan manajemen limbah selama perawatan. Pengunaan vacuum aerosol dapat mengurangi kontaminasi aerosol yang mengandung agen mikroba. ${ }^{45}$ Semua limbah yang terkontaminasi darah harus dibuang ke kantong sampah berwarna merah dan kantong sampah berwarna merah harus ditutup rapat, hal ini perlu dilakukan karena limbah dari fasilitas kesehatan gigi dan mulut dapat menimbulkan risiko penularan infeksi. ${ }^{3}$ Setelah selesai perawatan gigi dan mulut penting untuk melakukan sterilisasi dan disinfeksi alat dan ruang praktik. Sterilisasi bur dengan autoclave mampu 100\% menghilangkan kontaminasi mkiroorganisme dibanding dengan alkohol 70\% yang mampu menghilangkan kontaminasi mikroorganisme 93,3\%26. Disinfeksi digunakan pada benda mati dapat menghancurkan sel-sel mikroorganisme penyebab infeksi. ${ }^{21}$

\section{KESIMPULAN}

Tujuan utama dari beberapa artikel adalah bahwa pedoman pencegahan dan pengendalian infeksi dalam perawatan gigi dan mulut adalah sangat diperlukan. Kecenderungan dan tingginya risiko dokter gigi terinfeksi penyakit menular mendorong perhatian dari berbagai pihak terkait untuk mengatasinya. Beberapa kasus dalam literatur menunjukkan pentingnya pencegahan dan pengendalian infeksi dalam pelayanan kesehatan gigi dan mulut. Beberapa pedoman pencegahan dan pengendalian infeksi sebelumnya sudah ada, tetapi belum menyeluruh atau komprehensif. Seiring bertambahnya kasus penyakit infeksi saat ini, maka perlu membuat pedoman pencegahan dan pengendalian infeksi dalam pelayanan kesehatan gigi dan mulut secara komprehensif yang mencegah terjadinya penularan agen infeksius antara tenaga kesehatan terhadap pasien dan sebaliknya. 


\section{UCAPAN TERIMAKASIH}

Ucapan terima kasih kepada pihak yang telah mendukung dalam penulisan artikel ini yaitu dosen pembimbing dan segenap civitas Program Studi Doktor Kesehatan Masyarakat Fakultas Kesehatan Masyarakat Universitas Diponegoro serta Fakultas Kedokteran Gigi Universitas Muhammadiyah Semarang.

\section{DAFTAR PUSTAKA}

1. M.Greenwood JGM. General Medicine and Surgery for Dental Practitioners: Infections and Infection Control 19. 2019;221-33. Available from: https://link.springer.com/chapter/10.1007\% 2F978-3-319-97737-9_19

2. Panesar, SS., Stevens, AC., Salvilla, SA., Sheikh A. At a Glance Keselamatan Pasien dan Peningkatan Mutu Pelayanan Kesehatan. Erlangga; 2017. 58-60 p.

3. Sarhan A. Transmission and Prevention of Microbial Infection in Dental Healthcare Settings. 2020;(June).

4. Volgenant CMC, Soet JJ De. Crosstransmission in the Dental Office : Does This Make You III ? 2018;221-8.

5. Abbas AK et al. Hepatitis B Virus among Dental Clinic Workers and the Risk Factors Contributing for its Infection. Online J Dent Oral Heal. 2018;1(2):6-11.

6. Al-Kebsi AM. Sero-Prevalence of Hepatitis C Virus Among Dental Clinic Workers in Sana'a City- Yemen and the Risk Factors Contributing for Its Infection. Univers $\mathrm{J}$ Pharm Res. 2017;2(5):28-33.

7. Hoshyari N, Allahgholipour Z, Ahanjan M, Moosazadeh M. Evaluation of Bacterial Contamination in Clinical Environment of Sari Dental School in 2018. 2018;

8. Valeriani F, Protano C, Gianfranceschi G, Cozza P, Campanella V, Liguori G, et al. Infection control in healthcare settings: perspectives for mfDNA analysis in monitoring sanitation procedures. BMC Infect Dis [Internet]. 2016;1-10. Available from: http://dx.doi.org/10.1186/s12879-0161714-9

9. Kobza J, Pastuszka JS, Br E. Do exposures to aerosols pose a risk to dental professionals ? 2018;(June):454-8.

10. Aslam MRA, Suryawati C, Agushybana F. Importance of Prevention and Control of Coronovirus Disease (Covid-19) in Dental and Oral Hospital. J Ilmu Kesehat Masy. 2020;11(2):89-100.
11. Farahat TM, Hegazy N, Mohammed MA. The Assessment of Infection Control Measures in Dental Clinics Primary Health Care , Bilqas , Dakahlia. 2020;81(October):1621-7.

12. Shah AF, Baba IA. Knowledge and practices of infection control procedures in a Government Dental College setting ARTICLE INFO : 2016;4(4):364-7.

13. Yadav BK, Rai AK, Agarwal S, Yadav B. Assessment of infection control practice in private dental hospital Original Research Article Assessment of infection control practice in private dental hospital. 2017;(October).

14. Ayub, K., Durrani, OK., Shakeel, M., Qureshi $\mathrm{K}$. An audit of infection control in a tertiary care dental 00 hospital. POJ. 2019;11(1):33-8.

15. Kementerian Kesehatan Republik Indonesia. Standar Pencegahan dan Pengendalian Infeksi Pelayanan Kesehatan Gigi dan Mulut di Fasilitas Pelayanan Kesehatan. 2012. 30-31 p.

16. Kemenkes. Pedoman Pencegahan dan Pengendalian Infeksi di Fasilitas Pelayanan Kesehatan. 2017;(857).

17. Cumbo E, Gallina G, Messina $P$, Scardina GA. Alternative methods of sterilization in dental practices against COVID-19. Int $\mathrm{J}$ Environ Res Public Health. 2020;17(16):114.

18. Odeh ND, Babkair H, Abu-Hammad S, Borzangy S, Abu-Hammad A, Abu-Hammad O. COVID-19: Present and future challenges for dental practice. Int $\mathrm{J}$ Environ Res Public Health. 2020;17(9).

19. Fredy Mardiyantoro, Dyah Nawang Palupi Pratamawawi, Diena Fuadiyah, drg., M.Si., Lukman Hakim Hidayat, Edina Hartami, Farihah Septina AS. Dasar-Dasar Keselamatan Pasien pada Praktik Dokter Gigi. Universitas Brawijaya Press; 2019. 1$22 \mathrm{p}$.

20. Merza MA, Selivany BJ, Rashed M, Aldoski N. Prevalence of Hepatitis B and C Viruses among Patients Who Underwent Dental Interventions in a Dental Care Units at College of Dentistry, Duhok, Prevalence of Hepatitis B and C Viruses among Patients Who Underwent Dental Interventions in a Dental Care U. 2017;(November):0-4.

21. Mulyanti, Sri., Putri M. Pengendalian Infeksi Silang di Klinik Gigi. Buku Kedokteran EGC; 2019. 2-267 p.

22. Shah $A H, W y n e A H$. Cross Infection Control In Dentistry: A Review. Pakistan Oral Dent J. 2010;30(December):168-74.

23. Lumunon NP, Wowor VNS, Pangemanan DHC. Pencegahan dan Pengendalian 
Infeksi Silang pada Tindakan Ekstraksi Gigi di Poli Gigi Puskesmas Kakaskasen Tomohon. e-GIGI. 2019;7(1):34-43.

24. Ramadhani WR, Kepel BJ, Parengkuan WG. Tindakan Pencegahan Dan Pengendalian Infeksi Pada Perawatan Periodonsia Di Rumah Sakit Gigi Dan Mulut Pspdg Fk Unsrat. e-GIGl. 2015;3(2).

25. Raghunath N, Meenakshi S, Sreeshyla H, Priyanka N. Aerosols in Dental Practice- A Neglected Infectious Vector. Br Microbiol Res J. 2016;14(2):1-8.

26. Shahdad S, Patel T, Hindocha A, Cagney N, Mueller JD, Seoudi N, et al. The efficacy of an extraoral scavenging device on reduction of splatter contamination during dental aerosol generating procedures: an exploratory study. Br Dent J. 2020;1-10.

27. Dedy H, Yulianto K, Purwanti N, Utami TW, Dewi $A H$, Listyarifah $D$, et al. Dealing with the high-risk potential of COVID-19 crossinfection in dental practice. Maj Kedokt Gigi Indones. 2020;6(1):1-15.

28. Ali AA, Amin M, Jaffar S, Zaidi A, Baig QALI. PAKISTANI DENTISTS ATTITUDE TOWARDS CHAIRSIDE. 2017;37(2):32531.

29. Alharbi A, Alharbi S, Alqaidi S. Guidelines for dental care provision during the COVID19 pandemic. Saudi Dent J [Internet]. 2020;32(4):181-6. Available from: https://doi.org/10.1016/j.sdentj.2020.04.001

30. Diegritz C, Manhart J, Bücher K, Grabein B, Schuierer G, Kühnisch J, et al. A detailed report on the measures taken in the Department of Conservative Dentistry and Periodontology in Munich at the beginning of the COVID-19 outbreak. Clin Oral Investig. 2020;24(8):2931-41.

31. Hussein LM, Ali SD, Twair AMJ, Ali SD. Evaluation of Infection Control Measures of Iraqi Dentists in Dental Practices. Medicolegal Updat. 2020;20(2):268-73.

32. Nazir A, Usman N, KIRAN S, ZAHRA T, Khalid H, Akhtar MU. Cross Infection Control in Dental Institutions. Pakistan Oral Dent J [Internet]. 2018;38(4):419. Available from: https://search.proquest.com/docview/22547 77829 ?accountid $=17242$

33. Bialowska J, Bojar W, Zareba T, Tyski S, Tymczyna-Borowicz B. Microbiological purity of syringes containing composites in the context of cross-infection prevention in dental practices. Curr Issues Pharm Med Sci. 2020;33(2):102-5.

34. Abraham JP. An In Vitro Study To Compare The Effectiveness Of Decontamination Methods Used For Dental Bur. 2018;5(5).

35. Bourgeois D, Dussart C, Saliasi I, Laforest L, Tramini P, Carrouel F. Observance of
Sterilization Protocol Guideline Procedures of Critical Instruments for Preventing latrogenic Transmission of CreutzfeldtJakob Disease in Dental Practice in France , 2017. 2017;

36. Tasya N, Andriany P, Herwanda. Faktorfaktor yang Berhubungan dengan Pemanfaatan Pelayanan Kesehatan Gigi dan Mulut (RSGM) Universitas Syiah Kuala Banda Aceh. J Caninus Dent [Internet]. 2016;1(4):54-62. Available from: http://www.jim.unsyiah.ac.id/JCD/article/do wnload/1663/866

37. Manek O. Analysis Of Hospital Health Care, Health Facilities Level I Of BPJS Patients Satisfaction In Sikumana Public Health Centre Kupang. J Qual Public Heal. 2020;3(2):544-52.

38. Alwehaibi $M$ et al. Awareness and compliance of dental students and interns toward infection control at Riyadh Elm University. 2019;14:1-6.

39. Dagher J, Sfeir C, Abdallah A, Majzoub Z. Infection Control Measures in Private Dental Clinics in Lebanon. Int J Dent. 2017;2017.

40. Id RC, Leung SJ, Abel SN, Hatton MN, Ren $Y$, Seiver J, et al. HIV screening in the dental setting in New York State. 2020; Available from:

http://dx.doi.org/10.1371/journal.pone.0231 638

41. Peng X, Xu X, Li Y, Cheng L, Zhou X, Ren $B$. Transmission routes of 2019-nCoV and controls in dental practice. Int $\mathrm{J}$ Oral Sci [Internet]. 2020;12(1):1-6. Available from: http://dx.doi.org/10.1038/s41368-020-00759

42. Patil S, Moafa IH, Bhandi S, Jafer MA, Khan SS, Khan S, et al. Disease-a-Month Dental care and personal protective measures for dentists and non-dental health care workers. Disease-a-Month [Internet]. 2020;(xxxx):101056. Available from: https://doi.org/10.1016/j.disamonth.2020.10 1056

43. Bidra AS, Pelletier JS, Westover JB, Frank S, Brown SM, Tessema B. Comparison of In Vitro Inactivation of SARS CoV-2 with Hydrogen Peroxide and Povidone-lodine Oral Antiseptic Rinses. J Prosthodont. 2020;29(7):599-603.

44. Hargreaves KM. Journal of Endodontics. J Endod. 2009;35(7):A5-7.

45. S KN, Eachempati $P$, Paisi $M$, Nasser $M$, Sivaramakrishnan G, Jh V. dental procedures for preventing infectious diseases ( Review ). 2020; 